\title{
Partial suckling of lambs reduced the linoleic and conjugated linoleic acid contents of marketable milk in Chios ewes
}

\author{
O. Tzamaloukas, ${ }^{1}$ M. Orford, D. Miltiadou, and C. Papachristoforou \\ Department of Agricultural Sciences, Biotechnology and Food Science, Cyprus University of Technology, Lemesos, PO Box 50329, Cyprus
}

\begin{abstract}
The objective of this work was to investigate the effect of weaning systems applied in a commercial dairy sheep farm on the fatty acid (FA) composition of marketable milk produced. Forty second parity, purebred Chios ewes were allocated to the following weaning treatments: (a) ewes were weaned from their lambs at $48 \mathrm{~h}$ after birth and machine milked twice daily [no lambs (NL) group, $\mathrm{n}=20]$; or, (b) starting $48 \mathrm{~h}$ postpartum, ewes were separated from their lambs for 12 $\mathrm{h}$ during the evening, machine milked once daily the following morning, and lambs were allowed to suckle for $12 \mathrm{~h}$ during the day for the first $5 \mathrm{wk}$ of lactation [partial suckling (PS) group, $\mathrm{n}=20]$. After weaning of the PS lambs at wk 6 of age, all ewes were machine milked twice daily. Commercial milk yield and milk composition was recorded weekly (fat, protein, FA content) or fortnightly (somatic cell counts) throughout the first 10 wk of lactation. The PS ewes compared with NL group produced commercial milk lower in milk yield, milk fat, and somatic cell counts, but not in protein content during the first 5 -wk period. Such differences were not observed after weaning of the PS lambs. The FA profile of commercial milk was also affected by partial suckling during the preweaning period. Total polyunsaturated FA were higher in NL compared with PS ewe milk at wk 1, 2, 4, and 5 (on average, $21 \%$ higher), whereas no differences were detected between NL and PS ewe milk from wk 6 to 10 of lactation. From the polyunsaturated FA, linoleic acid (C18:2 cis-9,cis-12) and conjugated linoleic acid (C18:2 cis-9,trans-11; rumenic acid) were particularly affected, showing on average a reduction of 18 and $38 \%$, respectively. From the monounsaturated FA, vaccenic acid (C18:1 trans-11) was affected during wk 1 and 2 of the treatment period, with the PS ewe milk having reduced content compared with the NL milk. Other unsaturated FA, such as oleic acid and $\alpha$-linolenic acid, or saturated FA were not found to be affected by the weaning treatment. The results indicate
\end{abstract}

Received June 28, 2014.

Accepted November 12, 2014.

${ }^{1}$ Corresponding author: ouranios.tzamaloukas@cut.ac.cy that partial suckling of lambs during the first $5 \mathrm{wk}$ of lactation adversely affected both the total fat content of milk obtained by machine milking of their dams and the unsaturation content of the milk fat. Particularly affected were the linoleic acid and cis-9,trans-11 conjugated linoleic acid content of ewe milk.

Key words: weaning, polyunsaturated fatty acid, sheep, rumenic acid

\section{INTRODUCTION}

Dairy products made from ovine milk are economically important in many Mediterranean countries (Boyazoglu and Morand-Fehr, 2001). Knowledge of the FA composition of sheep milk, which is rich in fat, is important for reasons related to human health. Although controversial (Siri-Tarino et al., 2010) the consumption of SFA has been linked to increased risk of cardiovascular disease, whereas the consumption of other lipids, such as CLA (C18:2 cis-9,trans-11; rumenic acid), vaccenic acid (C18:1 trans-11), or total PUFA, has been considered as contributing to the prevention of atherosclerosis, osteoporosis, or cancer (WHO/FAO, 2002; Huth et al., 2006). As a result, research during the last decade has focused on the variation of FA content in ruminant milk due to nutrition (Sterk et al., 2012), genetics (Stoop et al., 2008), or management practices such as organic and low-input farming (Butler et al., 2008, 2011), whereas other management practices have attracted little attention. A management practice known to affect fat content of commercial milk produced by ruminants is the partial suckling of the offspring reported both in sheep (Papachristoforou, 1990; Fuertes et al., 1998; McKusick et al., 2001) and cows (Bar-Peled et al., 1995; Cozma et al., 2013).

Partial suckling systems, although not common in dairy cattle, are extensively applied in dairy sheep in many parts of the world, usually during the first 4 to 6 wk of lactation. The application of partial suckling in sheep is a means of increasing marketable milk yield compared with continuous suckling, as the amount of milk produced during the suckling period represents approximately $30 \%$ of the total ewe milk production (Folman et al., 1966; Louca, 1972; Lawlor et al., 1974). 
Several partial suckling systems have been investigated in relation to their effects on milk yield and lamb growth (Folman et al., 1966; Papachristoforou, 1990; McKusick et al., 2001), and evidence exists to support their economic superiority as compared with a traditional system of continuous lamb suckling until weaning or a more intensive system where lambs are separated from their dams immediately after birth and artificially reared on milk replacer (McKusick et al., 2001). However, the main disadvantage of partial suckling systems is the lower fat percentage (approximately 20\% reduction) of marketable milk obtained from ewes during the partial suckling period, which has a significant effect on both price and dairy processing characteristics of sheep milk (Marnet and Komara, 2008; Jaeggi et al., 2008).

The FA profile of commercial ovine milk obtained during partial suckling has not been previously studied and the variation of different FA (i.e., SFA, PUFA, or essential FA) in marketable ewe milk during this early lactation period is largely unknown. Earlier studies have reported the ability of the suckling ewe to withhold a certain amount of milk and milk fat within the udder (alveolar milk) during machine milking and release it in subsequent suckling by the lambs (Papachristoforou, 1990). More recently, McKusick et al. (2002) investigated the composition of alveolar and cisternal milk fractions of East Friesian dairy ewes under partial suckling and provided evidence of an inhibition of milk fat transfer from the alveoli to the cistern of the ewe udder during machine milking, whereas other milk components were unaffected. McKusick et al. (2002) also reported a tendency for a specific FA, octadecenoic acid (sum of C18:1 isomers), to be higher in the alveolar fraction of milk compared with the cisternal fraction, suggesting a different distribution of individual FA within the udder when partial suckling was applied. Furthermore, a recent study of Cozma et al. (2013), investigating the effects of the calf presence or suckling during early lactation in different cattle breeds, reported an effect on FA content of milk produced during treatment. Those authors indicated that calf presence or suckling during cow milking significantly reduced C18:0, C18:2 n-6, C18:3 n-3, and total PUFA percentage in milk fat. To the best of our knowledge, similar research has not been conducted in dairy sheep.

The objectives of the present study were to determine (a) the effect of partial suckling of lambs on FA content of marketable milk obtained by their dams during machine milking, and (b) any carry-over effect of this management practice on FA content of ewe milk after weaning of lambs. These effects were studied during the first $10 \mathrm{wk}$ of lactation, when most changes in milk FA content are likely to occur (Bauman and Griinari, 2003). Along with these objectives, the effect of weaning system on other production traits such as milk yield, composition, and quality (SCC) were also investigated.

\section{MATERIALS AND METHODS}

\section{Experimental Design}

Forty second-parity, purebred Chios ewes were selected from a commercial farm according to stage of pregnancy, age, and live weight and were used in the present experiment during the winter of 2012 to 2013. The animals were randomly allocated to 2 homogeneous subgroups which were balanced for the number of offspring and the live weights of ewes after parturition (average: 1.8 lambs per ewe, live weight \pm SEM of ewes: $58.2 \pm 0.6$ ). The 2 groups were assigned to 2 different weaning systems. (1) Ewes were weaned from their lambs at $48 \mathrm{~h}$ postpartum and machine milked twice daily, and their lambs reared artificially on milk replacer [no lambs $(\mathbf{N L})$ group, $\mathrm{n}=20$ ]. (2) Beginning $48 \mathrm{~h}$ postpartum, ewes were separated from their lambs for $12 \mathrm{~h}$ during the evening (from 1930 to $0730 \mathrm{~h}$ ), machine milked once daily the following morning, and their lambs were allowed to suckle for $12 \mathrm{~h}$ during the day [partial suckling (PS) group, $\mathrm{n}=$ 20]. Lambs of the PS group were kept in nearby pens during the night, allowing for audio and olfactory but not visual contact with their dams. At the end of wk 5 , lambs from the PS group were weaned and ewes were subsequently machine milked twice daily for the rest of the study.

All animals from both treatments were housed indoors in adjacent pens and were group fed the same TMR diet to 1.1 times their maintenance energy (0.401 $\mathrm{MJ} / \mathrm{kg}$ of weight $\left.\mathrm{H}^{0.73}\right)$ and milk production requirements [dietary ME $(\mathrm{MJ} / \mathrm{kg}$ of milk): $\mathrm{Y}=(1.94+0.43 \mathrm{X}) / 0.62$, where $\mathrm{X}$ is the fat percentage and 0.62 the efficiency of utilization of dietary ME for milk production of Chios ewes; Economides, 1986]. The ewe diet consisted of cereal straw and a concentrate ration of barley grain, whole corn, sugar beet pulp, soybean meal, along with vitamin trace element mixture (DSM Nutritional Products, Ayrshire, UK) to meet the requirements of the lactating ewes (NRC, 2007). Concentrate chemical composition was $907 \mathrm{~g}$ of $\mathrm{DM} / \mathrm{kg}, 954 \mathrm{~g}$ of OM/ $\mathrm{kg}$ of DM, $22 \mathrm{~g}$ of ether extract $/ \mathrm{kg}$ of DM, $155 \mathrm{~g}$ of $\mathrm{CP} / \mathrm{kg}$ of DM, $238 \mathrm{~g}$ of NDF $/ \mathrm{kg}$ of DM, and $166 \mathrm{~g}$ of $\mathrm{ADF} / \mathrm{kg}$ of DM, measured according to standard ISO methods [ISO, 1999b, 2002a, 1999a, 2009, 2006, and 2008 for moisture, ash, ether extract, CP, NDF and ADF, respectively). The feed was offered thrice (0600, 1200, and $1600 \mathrm{~h}$ ) daily. Animal weights were recorded fortnightly throughout the experiment. 
All lambs were allowed to receive colostrum and suckle their dams for $48 \mathrm{~h}$ after birth. From d 3 postpartum onwards, NL ewes were machine milked twice (0700 and $1900 \mathrm{~h}$ ) daily, whereas the PS ewes were milked once daily $(0700 \mathrm{~h})$ for the first 5 wk and twice $(0700$ and $1900 \mathrm{~h})$ for the rest of lactation. The milking machine (Fullwood Ltd., Shropshire, UK) was set to provide 160.4 pulsations per minute in a ratio 55:45, with a vacuum level of $41.4 \mathrm{kPa}$. Following the morning milking, individual milk samples of $50 \mathrm{~mL}$ were taken from all ewes every week and immediately transferred to the laboratory for determining milk composition (fat and protein), whereas a subsample of $5 \mathrm{~mL}$ was stored at $-20^{\circ} \mathrm{C}$ for subsequent analysis regarding milk FA content. Evaluation of milk somatic cells was also carried out on the sampling day during wk 2, 4, 6, 8, and 10 from all animals. As a standard procedure, immediately following milking, both teats were dipped in aqueous iodophor-based teat dips, and commercial milk production was recorded weekly throughout the experiment.

\section{Milk Analysis}

All milk samples collected during the study were evaluated for total fat and protein content using combined thermo-optical procedures (LactoStar 3510, Funke Gerber, Berlin, Germany) previously calibrated for protein using the Lowry protein assay (Lowry et al., 1951) and for fat using method 989.05 (AOAC International, 2005). For the isolation of fat from milk, the rapid double centrifugation method of Feng et al. (2004) was used with slight modifications. Briefly, 1.5$\mathrm{mL}$ aliquots of fresh milk were first centrifuged at 17,800 $\times g$ for $30 \mathrm{~min}$ at $4^{\circ} \mathrm{C}$. The resulting fat cakes were removed, placed in fresh tubes, and allowed to melt at room temperature for $20 \mathrm{~min}$. The samples were then recentrifuged at $19,500 \times g$ for $20 \mathrm{~min}$ at room temperature and $20-\mathrm{mg}$ aliquots of the resulting lipid cake were removed to fresh tubes and dispersed in $1 \mathrm{~mL}$ of n-hexane by shaking. Fatty acid methyl esters were prepared by transesterification with methanolic potassium hydroxide according to the ISO (2002b) method. Essentially, either $40 \mu \mathrm{L}$ of transesterification reagent $(11.2 \%$ $\mathrm{KOH}$ in methanol) were added to the tubes containing extracted lipid from milk $(1 \mathrm{~mL})$ and shaken vigorously for $1 \mathrm{~min}$. The tubes were then allowed to incubate for a further 5 min at room temperature before the addition of $0.1 \mathrm{~g}$ of sodium bisulfate. The particulate material was then removed by centrifugation at $350 \times g$ for $3 \mathrm{~min}$ at room temperature and aliquots of the clear organic phase transferred to amber gas chromatography vials and stored at $-70^{\circ} \mathrm{C}$ until analyzed. Fatty acid profiles were generated by analyzing the FAME samples on a GCMS-QP2010 Plus Gas Chromatography Mass Spectrometer (Shimadzu, Duisburg, Germany) equipped with an HT280T auto sampler (HTA, Brescia, Italy). Typically $1-\mu l$ aliquots of FAME were separated with a split ratio of 1:20 using an Agilent CP-Sil 88 fusedsilica capillary column $(50 \mathrm{~m} \times 0.25 \mathrm{~mm}$ internal diameter $\times 0.2 \mu \mathrm{m}$ film thickness). The column was held for $1 \mathrm{~min}$ at $80^{\circ} \mathrm{C}$ after injection, increased at $20^{\circ} \mathrm{C} /$ min to $120^{\circ} \mathrm{C}$, then raised to $193^{\circ} \mathrm{C}$ at $1^{\circ} \mathrm{C} / \mathrm{min}$, and finally increased to $220^{\circ} \mathrm{C}$ at $5^{\circ} \mathrm{C} / \mathrm{min}$. Helium was the carrier gas at $1 \mathrm{~mL} / \mathrm{min}$, with both injector and interface temperatures of $225^{\circ} \mathrm{C}$. Chromatographic profiles were analyzed using Shimadzu GCMS Postrun Solution software where individual peaks were identified by comparison of their retention indices to those of commercially available authentic standards (Supelco 37-FAME standard mix, cis-9,trans-11 CLA, trans-10,cis-12 CLA, trans-11 C18:1; Sigma-Aldrich, Gillingham, UK) using the National Institute of Standards and Technology 08 and 21 mass spectral libraries and cross referencing with chromatograms-spectrograms reported in the literature (Kramer et al., 2008; Christie and Han, 2010; Tsiafoulis et al., 2014). All FAME peaks identified were quantitated by peak integration and individual FAME expressed as a percentage of the total, as this quantification method is widely used and allows sound comparisons of FA profiles in milk samples (Butler et al., 2011).

Evaluation of milk somatic cells on milk samples was carried out using flow cytometry according to a modified method of Boulaaba et al. (2011). Briefly, aliquots of fresh milk $(1 \mathrm{~mL})$ were diluted with $4 \mathrm{~mL}$ of cold PBS and centrifuged at $300 \times g$ for $15 \mathrm{~min}$ at $4^{\circ} \mathrm{C}$. The supernatants were decanted and the insides of the tubes were gently wiped with paper tissue to ensure that all traces of the fat cake had been removed. The cell pellets were then resuspended in $1 \mathrm{~mL}$ of cold PBS and recentrifuged at $200 \times g$ for $10 \mathrm{~min}$ at $4^{\circ} \mathrm{C}$. After carefully removing the supernatants with a pipette, the resulting pellets were resuspended in $0.5 \mathrm{~mL}$ of PBS containing a $1 \times$ dilution of SYBR Safe DNA stain (Invitrogen, Carlsbad, CA) and allowed to incubate at room temperature for $5 \mathrm{~min}$ before fluorescence-activated cell sorting analysis. Flow cytometry was performed on an Accuri C6 Flow cytometer (Becton Dickinson, Oxford, UK), typically with an acquisition of 40,000 events, using a threshold value of 200,000. Total events were visualized on standard FSC-A (forward scatter) versus SSC-A (side scatter) plots and somatic cells counted as events falling in the upper positive quadrants of FSC-A versus FL1-A (fluorescence 530/30 nm filter) plots after setting the limits using an unstained sample. 


\section{Dependent Variable and Statistical Analysis}

Dependent variables included test day milk yield, percentage of milk fat and protein, SCC, individual FA content, and the following groups of FA selected due to their quantity, unsaturation level, or biological interest: SFA, short-chain saturated C4:0 to C10:0, mediumchain saturated $\mathrm{C} 12: 0$ to $\mathrm{C} 14: 0$, long-chain saturated C16:0 to C24:0, odd-chain saturated C5:0 to C15:0, MUFA, and PUFA. Data were analyzed by a mixed linear model using the statistical language $\mathrm{R}$ ( $\mathrm{R}$ Core Team, 2014) and the function lme from package nlme (Pinheiro and Bates, 2000).

The mixed model used the previously mentioned dependent variables, the weaning system (group) and the week of lactation as independent variables, whereas the ewe was used as a random variable following the mathematical model:

$$
\mathrm{Y}_{\mathrm{ijk}}=\mu+\alpha_{\mathrm{i}}+\beta_{\mathrm{j}}+(\alpha \beta)_{\mathrm{ij}}+\mathrm{b}_{\mathrm{k}}+\varepsilon_{\mathrm{ijk}},
$$

where $Y_{i j k}$ is the value of the response dependent variable for the ith group, in the jth week, for the kth ewe; $\mu$ is the overall mean response; $\alpha_{i}$ is the fixed main effect of weaning system (group level $\mathrm{i}=1,2$ ); $\beta_{\mathrm{j}}$ is the fixed main effect of week of lactation (week level $\mathrm{j}=1, \ldots, 10) ;(\alpha \beta)_{\mathrm{ij}}$ is the interaction between main effects; $b_{k}$ is the random effect of ewe (level $k=1, \ldots$, 40) corresponding to each of the 40 ewes; and $\varepsilon_{\mathrm{ijk}}$ is the random error. The significance of the parameters of the model was evaluated, and in case of nonsignificance the model was recalculated including only the significant parameters. To account for the repeated measurements model for the heteroscedasticity of the within-group errors, the varIdent structure was used (Pinheiro and Bates, 2000). This structure represents a variance model with different variances for each of the 40 ewes. The comparisons between the different combinations of the interaction of variable group and week were done using multiple hypothesis tests. The Tukey's Honestly Significant Difference procedure was used in multiple comparisons to control the family-wise error rate using the function glht from the package multcomp (Bretz et al., 2010) of the $\mathrm{R}$ statistical language.

\section{RESULTS}

\section{Ewe Production and Milk Composition}

The mean yield and content of fat, protein, and SCC of commercial milk obtained from the PS and NL groups are presented in Figure 1A to D. Weaning system affected marketable milk yield during the first 5 wk of lactation $(P<0.001)$, when lambs of the PS group were allowed to suckle their dams (Figure 1A). Ewes managed with the NL system produced, on average, $40 \%$ more commercial milk per day (approximately $25 \mathrm{~kg}$ for the 5-wk period) than the PS ewes machine milked once daily. After weaning of lambs from PS ewes, both groups produced similar yield of commercial milk, on average $1.67 \mathrm{~kg}$ per animal per day.

Before weaning, the fat content of marketable milk was affected by the weaning system $(P<0.001)$ in each weekly sampling (wk 1 to 5 of lactation; Figure 1B). The results demonstrated that PS ewes had, on average, $31 \%$ lower milk fat content $(P<0.001)$ than NL ewes during the first 5 -wk period (average of milk fat percentage was 3.2 and 4.7 for the PS and NL groups, respectively). This suppression of milk fat was not observed in the following period (wk 6 to 10); thus, no carry-over effect of the partial suckling system on milk fat content was observed (average of milk fat percentage during wk 6 to 10 was 5.2 and 5.1 for the PS and NL groupa, respectively). In contrast to fat, the milk protein was not affected by weaning treatment during the first 5 wk of lactation, showing similar content between groups with no difference in any of the 5 samplings (wk 1 to 5; Figure 1C). However, immediately after weaning and specifically on wk 6 , the PS ewes produced milk higher in protein $(P=0.039)$ compared with milk from NL ewes. For the rest of the experimental period (wk 7, 8, 9, and 10), the composition of milk was not different in protein content between groups, (overall mean of 4.67 and $4.78 \%$ for the NL and PS groups, respectively). The somatic cells in ewe milk, measured fortnightly, were affected by the weaning system (Figure 1D). Ewes under the partial suckling system had lower SCC per milliliter of milk compared with ewes from NL group $(P=0.001$ and 0.003 for wk 2 and 4 , respectively). Following weaning, no differences in SCC between treatments were observed and values for both PS and NL groups were similar in milk collected on wk 6,8 , and 10, ranging from 4.81 to $5.24 \log$ units, corresponding to 64,500 to 173,700 cells $/ \mathrm{mL}$ of milk. Animal weights were similar between the PS and NL groups throughout the experimental period (average \pm $\mathrm{SEM}=58.5 \pm 1.25 \mathrm{~kg}$ ), and the consumption of feed on offer was similar (no residuals left in both groups).

\section{Milk Fat Composition}

The descriptive statistics of the individual analyzed FA and the calculated groups of FA determined in Chios sheep milk in both the PS and NL groups of the present study are given in Table 1. Approximately $74 \%$ (wt/wt) of the milk fat was identified as SFA, and from these the highest proportion was the $\mathrm{C} 16: 0$ to 24:0 (35\% wt/wt) followed by C12:0 to 14:0 (20\% wt/ 

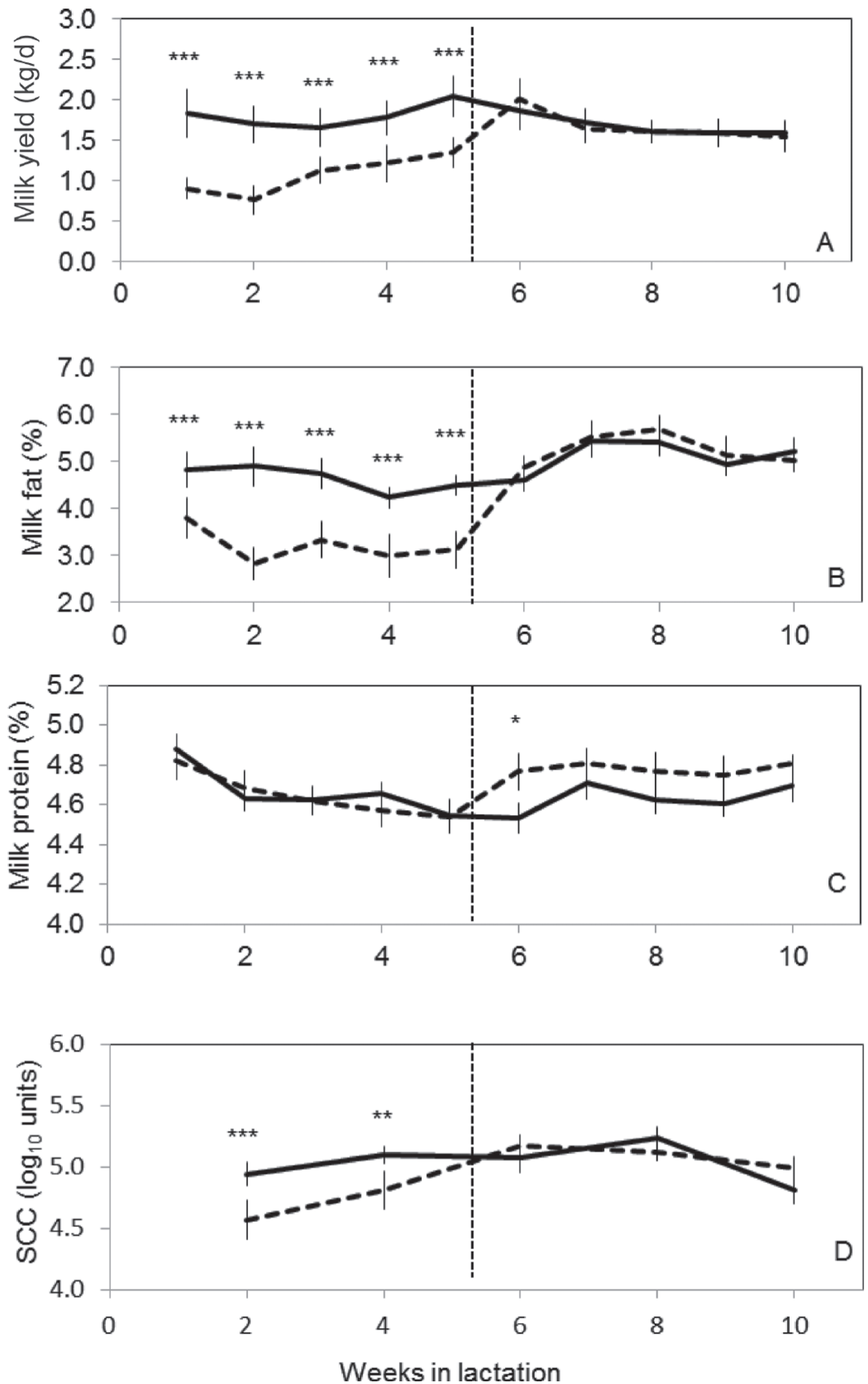

Figure 1. Means of commercial milk yield, milk fat, milk protein, and milk SCC in panels A, B, C, and D, respectively, for the 2 treatment groups: no lamb (NL) ewes, weaned of their lambs at $48 \mathrm{~h}$ postpartum and machine milked twice daily (solid line, $\mathrm{n}=20$ ), and partial suckled (PS) ewes, machine milked once daily for the first $5 \mathrm{wk}$ of lactation (dashed line, $\mathrm{n}=20$ ). Error bars indicate $95 \%$ CI for each test-day observation. The vertical dotted line indicates time of weaning of the PS ewes $\left({ }^{*} P<0.05,{ }^{* *} P<0.01,{ }^{* * *} P<0.001\right)$. 
wt) and C4:0 to 10:0 (18\% wt/wt). Milk fat from the present experiment contained $4.1 \%$ (wt/wt) of PUFA, whereas approximately $2 \%$ of the fat was unidentified. The most abundant individual FA (expressed in wt/ wt) were C16:0 (25.16\%), C18:1 cis-9 (19.2\%), C14:0 (12.04\%), and C10:0 (9.79\%). Table 1 also shows the effect of weaning treatment on FA content in milk fat, whereas the change of selected FA during the first 10 wk of lactation for both PS and NL ewes are shown in Figure $2 \mathrm{~A}$ to J. The interaction of weaning system $\times$ week of observation was a significant source of variation for almost all FA. Multiple comparisons between different groups (PS and NL) at different time intervals (wk 1 to 10) showed an effect of weaning system on milk FA composition.

Weaning system affected the amount of PUFA (Figure $2 \mathrm{C})$ in commercial milk fat at wk $1(P<0.001)$, $2(P<0.001), 4(P<0.001)$, and $5(P<0.01)$, with the NL milk containing on average $21 \%$ more PUFA than the PS commercial milk. This difference was not sustained after wk 5, when lambs were weaned in the PS group, and PUFA were similar for the following test-day observations [average PUFA values for the wk 6 to 10 were 3.9 and $4.1 \%$ (wt/wt) for the PS and NL groups, respectively]. The results from individual PUFA showed different pattern to one another. Linoleic acid (C18:2 n-6; Figure 2E) and rumenic acid (cis-9,trans-11 CLA; Figure 2F) were affected by suckling treatment, whereas no effect was observed for $\alpha$-linolenic (C18:3 n-3; Figure 2G) and arachidonic acids (C20:4 n-6; Figure $2 \mathrm{H}$ ). The results showed that before weaning, C18:2 n-6 content of marketable milk from PS ewes was lower compared with NL on wk $1(P<0.001), 2(P<0.001)$, $4(P<0.01)$, and $5(P<0.01)$, averaging about a $22 \%$ (wt/wt) reduction in linoleic acid of commercial milk of the PS group during the partial suckling period. After lamb weaning, the percentage of linoleic acid in milk fat of PS ewes was similar to that observed in milk from NL ewes [overall mean values for the following weeks were 2.96 and $2.86 \%$ (wt/wt) for PS and NL milk, respectively]. Rumenic acid followed similar pattern with linoleic acid and PUFA, with a weaning system effect during the first 5 -wk period $(P<0.01$ for wk $1,2,4$, and 5) and no effect on CLA content of PS and NL commercial milk after weaning of PS lambs.

The content of different MUFA was also affected differentially by the weaning system. Thus, oleic acid percentage (C18:1 cis-9; Figure 2I) in commercial milk of the PS and NL groups was similar throughout the 10 -wk period [average $=19.11$ and $19.22 \%$ (wt/wt) for the PS and NL groups, respectively], whereas the vaccenic acid (C18:1 trans-11; Figure 2J) were affected during the early lactation $(P<0.001$ for wk 1 and 2 ). For the following partial suckling period (wk 3 to
$5)$, the content of vaccenic acid in PS commercial milk was not reduced compared with the NL group. Similar to the other FA, no carry-over effect was detected following weaning of the PS lambs. The total MUFA percentage in commercial milk followed the pattern of the biggest MUFA isomer, oleic acid, with no effect of weaning system at any time during the experiment (Figure 2B). The percentage of SFA in commercial milk was not statistically different between the PS and NL groups in any of the test-day weekly observations (Figure $1 \mathrm{~A}$ ), whereas no treatment effect was observed in the saturated groups tested: C5:0 to 15:0 (Figure 2D) or C4:0 to 10:0, C12:0 to 14:0, and C16:0 to 24:0 (data not shown).

\section{DISCUSSION}

To the best of our knowledge, ours is the first study providing evidence that the weaning system applied in sheep affects the FA profile of commercial milk obtained. Our results showed that PUFA content of commercial milk was significantly reduced in partially suckled ewes compared with the milk produced by ewes nursing no lambs (NL milk had approximately $21 \%$ more PUFA compared with PS). Most noticeably affected were the linoleic and rumenic acid content of marketable milk, whereas significant differences were also found in vaccenic acid at the beginning of lactation (wk 1 and 2). After weaning of lambs of the PS ewes, no differences were found between treatment groups in the milk content of any unsaturated or saturated FA up to wk 10 of lactation, indicating no carry-over effect of the weaning system on milk FA content.

The present experiment, in agreement with previous studies in partially suckled ewes (Papachristoforou, 1990; McKusick et al., 2001, 2002) and cows (Bar-Peled et al., 1995; Fröberg et al., 2008; Mendoza et al., 2010), showed a significant reduction of milk fat (on average $31 \%, P<0.001$ ) in commercial milk of PS ewes before but not after weaning. The underlying mechanism responsible for the suppression of fat during the partial suckling period is not fully elucidated, and 2 possible modes of action have been proposed: (1) reduced milk fat synthesis in the mammary gland or (2) partial inhibition of milk ejection during machine milking of the PS ewes, resulting in a reduction of fat transfer from the alveoli to the cistern and subsequently into marketable milk (McKusick et al., 2002). According to the first mechanism, the low fat of PS ewes involves an overall reduction of fat synthesis in the mammary gland during the partial suckling period. Thus, this hypothesis suggests that the suppression of synthesis is attributed to the presence of certain FA within the udder, which are known to play a regulatory role in mammary lipid me- 
Table 1. Descriptive statistics for the FA content of 400 morning milking samples of commercial milk obtained from Chios ewes under different weaning systems

\begin{tabular}{|c|c|c|c|c|c|}
\hline Variable $^{1}$ & $\begin{array}{c}\operatorname{Mean}^{2}(\%, \mathrm{wt} / \\
\text { wt) }\end{array}$ & SD & 5\% Quantile & 95\% Quantile & $\begin{array}{l}\text { Effect of } \\
\text { treatment }^{3}\end{array}$ \\
\hline $\mathrm{C} 4: 0$ & 2.50 & 0.47 & 1.90 & 3.39 & NS \\
\hline $\mathrm{C} 5: 0$ & 0.03 & 0.02 & 0.01 & 0.06 & NS \\
\hline C6:0 & 2.66 & 0.45 & 2.09 & 3.46 & NS \\
\hline C7:0 & 0.05 & 0.04 & 0.02 & 0.10 & NS \\
\hline $\mathrm{C} 8: 0$ & 3.02 & 0.53 & 2.30 & 3.91 & NS \\
\hline C9:0 & 0.08 & 0.04 & 0.04 & 0.17 & NS \\
\hline C10:0 & 9.79 & 1.63 & 7.32 & 12.56 & NS \\
\hline C10:1 cis-9 & 0.34 & 0.08 & 0.22 & 0.47 & NS \\
\hline $\mathrm{C} 11: 0$ & 0.12 & 0.06 & 0.05 & 0.25 & NS \\
\hline C12:0 & 6.04 & 0.97 & 4.47 & 7.68 & NS \\
\hline C12:1 cis-9 & 0.10 & 0.03 & 0.05 & 0.16 & NS \\
\hline C13:0 & 0.09 & 0.04 & 0.05 & 0.17 & NS \\
\hline isoC14:0 & 0.07 & 0.03 & 0.03 & 0.11 & NS \\
\hline C14:0 & 12.04 & 1.57 & 9.28 & 14.34 & NS \\
\hline isoC15:0 & 0.19 & 0.07 & 0.09 & 0.33 & NS \\
\hline $\mathrm{C} 14: 1$ cis-9 & 0.18 & 0.05 & 0.11 & 0.27 & NS \\
\hline anteisoC15:0 & 0.40 & 0.11 & 0.20 & 0.58 & NS \\
\hline C15:0 & 0.96 & 0.22 & 0.69 & 1.36 & NS \\
\hline isoC16:0 & 0.22 & 0.06 & 0.14 & 0.33 & NS \\
\hline C16:0 & 25.16 & 2.47 & 21.48 & 29.79 & NS \\
\hline C16:1 cis-9 & 0.79 & 0.21 & 0.51 & 1.15 & NS \\
\hline isoC17:0 & 0.30 & 0.08 & 0.17 & 0.44 & NS \\
\hline anteisoC17:0 & 0.46 & 0.15 & 0.27 & 0.73 & NS \\
\hline C17:1 cis-10 & 0.20 & 0.07 & 0.11 & 0.34 & NS \\
\hline C17:0 & 0.52 & 0.13 & 0.34 & 0.75 & NS \\
\hline isoC18 & 0.18 & 0.07 & 0.09 & 0.30 & NS \\
\hline C18:0 & 8.05 & 1.51 & 5.79 & 10.56 & NS \\
\hline C18:1 trans-11 & 1.37 & 0.42 & 0.98 & 1.76 & $P<0.001$ \\
\hline C18:1 cis-9 & 19.20 & 3.30 & 14.70 & 24.55 & NS \\
\hline C18:1 other & 0.14 & 0.06 & 0.05 & 0.25 & NS \\
\hline C18:2 cis-9,cis-12 & 2.93 & 0.52 & 2.22 & 3.81 & $P<0.01$ \\
\hline C18:2 other & 0.11 & 0.05 & 0.06 & 0.19 & NS \\
\hline C18:3 cis-6, cis-9, cis-12 & 0.07 & 0.03 & 0.04 & 0.12 & NS \\
\hline $\mathrm{C} 18: 3$ cis- 9, cis- 12, cis- 15 & 0.21 & 0.09 & 0.10 & 0.37 & NS \\
\hline $\mathrm{C} 20: 0$ & 0.16 & 0.03 & 0.11 & 0.22 & NS \\
\hline $\mathrm{C} 20: 1$ cis-9 & 0.06 & 0.03 & 0.04 & 0.10 & NS \\
\hline C18:2 cis-9,trans-11 (CLA) ${ }^{4}$ & 0.54 & 0.24 & 0.30 & 0.89 & $P<0.001$ \\
\hline C18:2 trans-10,cis-12 (CLA) & 0.07 & 0.03 & 0.04 & 0.12 & NS \\
\hline C20:4 cis-5,cis-8,cis-11,cis-14 & 0.22 & 0.06 & 0.14 & 0.31 & NS \\
\hline $\mathrm{C} 22: 0$ & 0.08 & 0.04 & 0.05 & 0.10 & NS \\
\hline SFA & 74.04 & 7.69 & 64.81 & 83.41 & NS \\
\hline $\mathrm{C} 4-10$ & 17.83 & 3.32 & 13.61 & 23.20 & NS \\
\hline C12-14 & 20.10 & 1.99 & 17.06 & 23.55 & NS \\
\hline C16-24 & 35.14 & 5.76 & 30.41 & 39.56 & NS \\
\hline C5-15 & 1.32 & 0.39 & 0.88 & 2.05 & NS \\
\hline MUFA & 22.54 & 3.24 & 17.68 & 28.35 & NS \\
\hline PUFA & 4.09 & 0.79 & 2.97 & 5.42 & $P<0.001$ \\
\hline
\end{tabular}

${ }^{1} \mathrm{SFA}=$ sum of SFA, C4-10 = sum of short-chain saturated C4:0 to C10:0, C12-14 = sum of medium-chain saturated C12:0 to C14:0, C16-24 = sum of long-chain saturated C16 to C24:0, C5-15 = sum of odd-chain saturated FA; MUFA = sum of MUFA, PUFA = sum of PUFA

${ }^{2}$ For each FA, reported as methyl esters, wt/wt proportion of the total fat fraction of $100 \%$ is presented.

${ }^{3}$ Effect of partial-suckling of lambs during the first 5 wk of lactation on FA content of sheep milk (level of significance identified is indicated, or NS for nonsignificant effect).

${ }^{4}$ Composite $(9,11)$ CLA isomers, in majority cis-9,trans-11 CLA (Tsiafoulis et al., 2014).

tabolism, inducing low fat content, known also as milk fat depression syndrome (Bauman and Griinari, 2003). Although some controversy still exists in the literature regarding the specific trans-C18:1 FA inducing low fat syndrome in ruminants (Lock et al., 2007), it is known that trans-10,cis-12 CLA is a potent inhibitor of mam- mary lipid synthesis in mice, rats, cows, sheep, and goats (Bauman et al., 2008). The present study showed no difference between treatments in that specific FA provided little support to such an effector mechanism through overall milk fat depression in the mammary gland of ewes under the partial suckling regimen. 

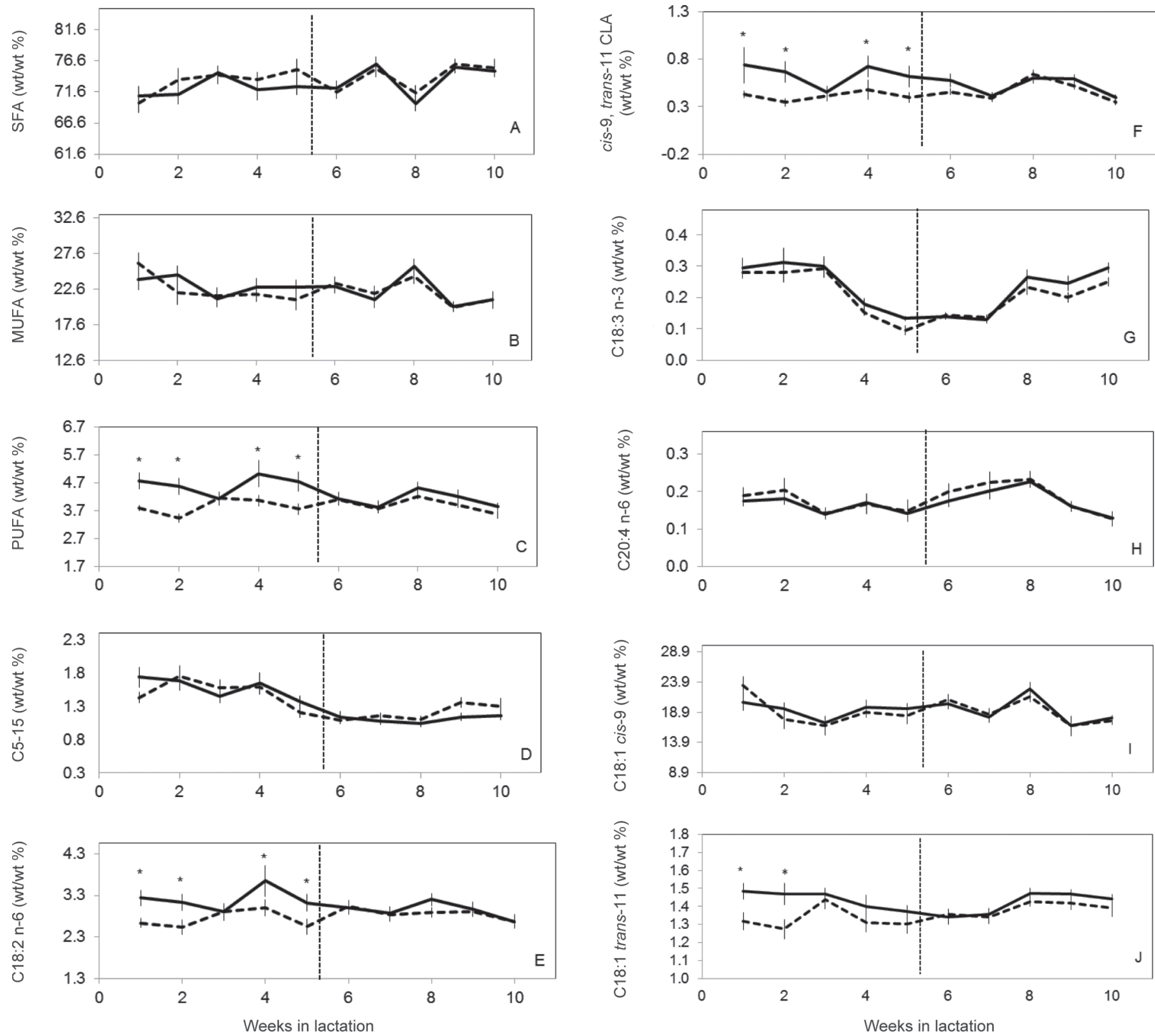

Figure 2. Means of FA percentage during the first $10 \mathrm{wk}$ of lactation of Chios sheep for the 2 following treatment groups: no lamb (NL) ewes weaned of their lambs at $48 \mathrm{~h}$ postpartum and machine milked twice daily (solid line, $\mathrm{n}=20$ ) and ewes were partially suckled (PS) and machine milked once daily for the first $5 \mathrm{wk}$ of lactation (dashed line, $\mathrm{n}=20$ ). The $\mathrm{y}$-axis shows the amount (\% wt/wt) of selected FA, reported as methyl esters, with the values ranging from -3 to 3 phenotypic SD, which facilitates comparison across different FA. Error bars indicate $95 \%$ CI for each test-day observation. The vertical dotted line indicates time of weaning of the PS ewes. An asterisk $(*)$ indicates a significant difference between treatments $(P<0.01)$. Refer to the text for descriptions of the FA groups studied.

In different sheep breeds around $75 \%$ of the milk fat secreted remains in the alveolar section and is only obtained when milk ejection occurs (Labussière, 1988). Fat globules of sheep milk, with a diameter of $3.3 \mu \mathrm{m}$, are large relative to animal body size, compared with $4.55 \mu \mathrm{m}$ for cow milk globules (Park et al., 2007). It has been suggested that ovine fat globules, similar to bovine ones, require active myoepithelial contraction for their transfer to the cistern and subsequent ejection from the udder (McKusick et al., 2002). It has been shown by the same authors that in milking ewes the milk fat percentage is higher in the alveolar compared with cisternal milk fraction, irrespective of the weaning system applied (McKusick et al., 2002). Also, under a partial suckling system, the cisternal milk is mainly obtained during machine milking, whereas a large part 
of alveolar milk is retained in the udder and released in the subsequent lamb suckling process (Papachristoforou, 1990; Marnet and Negrão, 2000; McKusick et al., 2002). This has sound physiological ground, as plasma oxytocin concentration in ewes under partial suckling is not increased above a baseline value during machine milking, whereas values of oxytocin are significantly increased during suckling of the same ewes (Marnet and Negrão, 2000). Previous work by Papachristoforou (1990) showed that a postmilking intravenous injection of oxytocin produced significantly more milk in partially suckled ewes than in those on a nonsuckling treatment. Furthermore, the study of McKusick et al. (2002), using oxytocin receptor antagonists, showed that only cisternal milk was obtained during machine milking of partially suckled ewes, and this milk was significantly lower in fat content compared with the alveolar milk obtained with exogenous oxytocin injection of the same animals (mean values of fat 2.09 and $6.87 \%$ in cisternal and alveolar milk, respectively). Thus, a relative inefficiency of milk ejection mechanism may be involved in the present study as well, affecting yield and fat percentage of commercial milk obtained from PS ewes similar to previous reports in Chios (Papachristoforou 1990), Lacaune (Marnet and Negrão, 2000), and EastFriesian dairy ewes (McKusick et al., 2001, 2002).

However, it is not known if this mechanism could have any possible effect on milk FA composition in milking ruminants under a partial suckling treatment, as observed by the present study with Chios ewes and previously with cows (Cozma et al., 2013). A possible explanation would be related to a change in milk fluidity, due to alteration of specific FA, and therefore the easier transfer of more fluid PUFA from the alveolar to the cisternal fraction of the udder and, subsequently, to the marketable milk of PS ewes. However, the milk collected from PS ewes during machine milking in the present study, was lower in PUFA content compared with NL ewes and therefore does not provide any support of such a hypothesis. Nevertheless, a recent study with Holstein dairy cows that investigated the variation in milk composition and FA profile during milking (Rico et al., 2014) showed an increase in fat concentration over the course of milk let down but a decrease of unsaturated FA, including linoleic acid and cis-9,trans-11 CLA. Other mechanisms may be involved in altering the milk FA content of commercial milk in suckling ewes, and this merits further investigation as the most affected FA by the suckling treatment was linoleic acid, 1 of the 2 essential FA in ruminant diets (McDonald et al., 2002).

The effect of weaning system on FA content of marketable ewe milk has not been reported before and, therefore, our results can be compared only with a pre- vious work of McKusick et al. (2002) examining the FA content of alveolar and cisternal milk of East Friesian dairy ewes under a partial suckling system. In agreement with the present results, McKusick et al. (2002) reported no differences in any saturated FA examined, whereas total $\mathrm{C} 18: 1$ was higher $(P<0.01)$ in alveolar compared with cisternal milk during the suckling period, but not after weaning of lambs. However, as no FA isomer separation between different C18:1 isomers was performed in that study, it is not known if the reported difference between alveolar and cisternal milk can be attributed to trans $\mathrm{C} 18: 1$, as observed in the present work, or was due to differences in other C18:1 isomers. Nonetheless, the study of McKusick et al. (2002) using East Friesian dairy sheep did not find any difference in total PUFA or total C18:2 between alveolar and cisternal milk, in contrast to the present study. This disagreement may be attributed to the udder characteristics of the sheep breed used in each experiment and further studies are needed to investigate any possible effect of breed, as this factor is known to affect udder morphology and milking characteristics (Bruckmaier et al., 1997).

The effect of partial suckling on FA content of commercial milk obtained by twice daily milking of 2 different breeds (Prim Holstein and Salers) was tested recently by Cozma et al. (2013) in cattle during the first 6 wk of lactation. Calf presence or suckling in Salers cows significantly increased milk yield and decreased milk fat content (2.68 and $3.53 \%$ of milk fat in the presence and the absence of calf treatment, respectively), whereas Prim Holstein cows were unaffected in terms of milk production or milk fat content (3.18 and 3.33\% of milk fat in the presence or absence of calf treatment, respectively). Interestingly, the FA composition of milk produced during the treatment period was significantly affected in both breeds. Calf presence or suckling treatment significantly decreased the linoleic acid (C18:2 cis-9,cis-12) and total PUFA content in commercial milk obtained from both Salers and Prim Holstein breed, in agreement to the present results of the PS Chios ewes. Furthermore, the calf presence or suckling treatment decreased the content of trans-C18:1 and cis9,trans-11 CLA in commercial milk of Salers cows, but not in Prim Holstein cows, suggesting an effect of breed on the udder response to the partial suckling. However, Cozma et al. (2013) reported a significant reduction in $a$-linolenic acid and a significant increase of C16:0 content of milk in both tested breeds as a result of calf presence or suckling treatment; these changes were not observed in the present experiment with Chios ewes under a partial suckling regimen. Nevertheless, the present study with Chios ewes and the previously reported studies in Prim Holstein and Salers cow breeds (Cozma 
et al., 2013) and East Friesian dairy ewes (McKusick et al., 2002) provide some evidence for the existence of an underlying mechanism regulating selective secretion of specific FA in milk collected during machine milking in response to the presence or suckling of offspring.

Regardless of the mechanism, the present study showed a significant effect of suckling treatment on fat content and FA profile, but not in protein content of milk obtained by the PS ewes. Unaffected protein content is in accordance with previous studies with partial suckling systems in sheep (Papachristoforou, 1990; McKusick et al., 2001, 2002) and cows (Bar-Peled et al., 1995; Mendoza et al., 2010) and could be attributed to the ability of the mammary gland to produce milk with similar protein concentrations regardless of the nutritional or the management practices applied (Walker et al., 2004; Jenkins and McGuire, 2006). In addition, the observed results on protein content do not contradict previously suggested mechanisms affecting fat, as casein micelles are diluted in the aqueous fraction of milk and, consequently, there is no need for active myoepithelial contraction for the protein transfer from the alveoli to the cistern and eventually to the commercial milk obtained during machine milking of PS ewes. However, the present study reported a tendency for increased protein content of PS milk after the cessation of the suckling treatment, reaching the level of significance only on wk 6 of lactation.

Somatic cell counts in ewe milk as well as mammary infection for both PS and NL groups were monitored throughout the present experiment and found to be at low levels in both groups. The results also showed that SCC were significantly lower for PS compared with NL ewes during the partial suckling period, in agreement to previous studies in sheep (McKusick et al., 2001) and dairy cows (Fröberg et al., 2008; Mendoza et al., 2010). This difference is likely attributed to the more frequent udder evacuation in PS ewes during the partial suckling period, and the effect was not present after weaning of lambs at wk 5 when the frequency of udder evacuation was reduced to twice daily.

\section{CONCLUSIONS}

The present study in Chios ewes confirmed that partial suckling of lambs during early lactation results in less marketable milk with lower fat content compared with complete weaning systems, where lambs are artificially fed and the ewes are machine milked twice daily postpartum. In addition, the present study demonstrated that the FA content, particularly the PUFA percentage, in marketable milk is also affected by the weaning system applied. Ewes on partial suckling system produced milk with fat approximately $21 \%$ lower in PUFA compared with nonsuckling ewes. The PUFA affected were an essential FA (linoleic acid), and cis-9,trans-11 CLA, both with possible beneficial attributes to human health. This information should be taken into account when dairy sheep producers decide which weaning system to adopt, as this could affect the fat quality of milk as well as the dairy end products.

\section{ACKNOWLEDGMENTS}

This work was funded by the Cyprus Research Promotion Foundation and the European Structural Fund (Lefkosia, Cyprus), and the Cyprus University of Technology (Lemesos). We thank the technical staff of the animal production section of the University and the collaborative commercial farm (Koinas Ltd., Avdimou, Cyprus) for the management of the Chios sheep flock. We also thank M. Hadjipanayiotou (Cyprus University of Technology) and the 2 anonymous reviewers for valuable suggestions on the manuscript. Special thanks to Nikolaos Mittas and Theodosios Theodosiou (Statnous Ltd., Thessaloniki, Greece; www.statnous.com) for their help and advice during the statistical analysis.

\section{REFERENCES}

AOAC International. 2005. Official Methods of Analysis. 18th ed. 1st rev. AOAC International Gaithersburg, MD.

Bar-Peled, U., E. Maltz, I. Bruckental, Y. Folman, Y. Kali, H. Gacitua, A. R. Lehrer, C. H. Knight, B. Robinzon, and H. Voet. 1995. Relationship between frequent milking or suckling in early lactation and milk production of high-producing dairy cows. J. Dairy Sci. 78:2726-2736.

Bauman, D. E., and J. M. Griinari. 2003. Nutritional regulation of milk fat synthesis. Annu. Rev. Nutr. 23:203-227.

Bauman, D. E., J. W. Perfield 2nd, K. J. Harvatine, and L. H. Baumgard. 2008. Regulation of fat synthesis by conjugated linoleic acid: Lactation and the ruminant model. J. Nutr. 138:403-409.

Boulaaba, A., N. Grabowski, and G. Klein. 2011. Differential cell count of caprine milk by flow cytometry and microscopy. Small Rumin. Res. 97:117-123.

Boyazoglu, J., and P. Morand-Fehr. 2001. Mediterranean dairy sheep and goat products and their quality: A critical review. Small Rumin. Res. 40:1-11.

Bretz, F., T. Hothorn, and P. Westfall. 2010. Multiple Comparisons Using R. Chapman \& Hall/CRC Press, Boca Raton, FL.

Bruckmaier, R. M., G. Paul, H. Mayer, and D. Schams. 1997. Machine milking of East Friesian and Lacaune dairy sheep: Udder anatomy, milk ejection and milking characteristics. J. Dairy Res. 64:163-172.

Butler, G., J. H. Nielsen, T. Slots, C. Seal, M. D. Eyre, R. Sanderson, and C. Leifert. 2008. Fatty acid and fat-soluble antioxidant concentrations in milk from high-and low-input conventional and organic systems: Seasonal variation. J. Sci. Food Agric. 88:1431-1441.

Butler, G., S. Stergiadis, C. Seal, M. Eyre, and C. Leifert. 2011. Fat composition of organic and conventional retail milk in northeast England. J. Dairy Sci. 94:24-36.

Christie, W. W., and X. Han. 2010. Lipid analysis: Isolation, Separation, Identification and Lipidomic Analysis 4th ed. Vol. 25 The Oily Press Lipid Library Series, Woodhead Publishing Ltd. Cambridge, UK.

Cozma, A., B. Martin, M. Guiadeur, P. Pradel, E. Tixier, and A. Ferlay. 2013. Influence of calf presence during milking on yield, com- 
position, fatty acid profile and lipolytic system of milk in Prim Holstein and Salers cow breeds. Dairy Sci. Technol. 93:99-113.

Economides, S. 1986. Comparative studies of sheep and goats: Milk yield and composition and growth rate of lambs and kids. J. Agric. Sci. 106:477-484

Feng, S., A. Lock, and P. Garnsworthy. 2004. Technical note: A rapid lipid separation method for determining fatty acid composition of milk. J. Dairy Sci. 87:3785-3788.

Folman, Y., R. Volcani, and E. Eyal. 1966. Mother-offspring relationships in awassi sheep. I: The effect of different suckling regimes and time of weaning on the lactation curve and milk yield in dairy flocks. J. Agric. Sci. 67:359-368.

Fröberg, S., E. Gratte, K. Svennersten-Sjaunja, I. Olsson, C. Berg, A. Orihuela, C. S. Galina, B. García, and L. Lidfors. 2008. Effect of suckling ('restricted suckling') on dairy cows' udder health and milk let-down and their calves' weight gain, feed intake and behaviour. Appl. Anim. Behav. Sci. 113:1-14.

Fuertes, J. A., C. Gonzalo, J. Carriedo, and F. San Primitivo. 1998. Parameters of test day milk yield and milk components for dairy ewes. J. Dairy Sci. 81:1300-1307.

Huth, P. J., D. B. DiRienzo, and G. D. Miller. 2006. Major scientific advances with dairy foods in nutrition and health. J. Dairy Sci. 89:1207-1221.

ISO (International Organization for Standardization). 1999a. Animal feeding stuffs: Determination of fat content ISO 6492:1999. ISO, Geneva, Switzerland.

ISO (International Organization for Standardization). 1999b. Animal feeding stuffs: Determination of moisture and other volatile matter content. ISO 6496:1999. ISO, Geneva, Switzerland.

ISO (International Organization for Standardization). 2002a. Animal feeding stuffs Determination of crude ash. ISO 5984:2002. ISO, Geneva, Switzerland

ISO (International Organization for Standardization). 2002b. Milk fat; Preparation of fatty acid methyl esters. ISO 15884:2002 (IDF 182:2002). ISO, Geneva, Switzerland.

ISO (International Organization for Standardization). 2006. Animal feeding stuffs - Determination of amylase-treated neutral detergent fibre content (aNDF). ISO 16472:2006 . ISO, Geneva, Switzerland.

ISO (International Organization for Standardization). 2008. Animal feeding stuffs-Determination of acid detergent fibre (ADF) and acid detergent lignin (ADL) contents ISO 13906:2008, Geneva, Switzerland.

ISO (International Organization for Standardization). 2009. Animal feeding stuffs - Part 1 Determination of nitrogen content and calculation of crude protein content-Part 2: Block digestion and steam distillation method. ISO 5983-2:2009. ISO, Geneva, Switzerland.

Jaeggi, J., W. Wendorff, Y. Berger, and M. Johnson. 2008. Impact of weaning system on composition and yield of a semi-soft ovine-milk cheese. Small Rumin. Res. 79:124-128.

Jenkins, T. C., and M. A. McGuire. 2006. Major advances in nutrition: Impact on milk composition. J. Dairy Sci. 89:1302-1310.

Kramer, J. K. G., M. Hernandez, C. Cruz-Hernandez, J. Kraft, and M. E. R. Dugan. 2008. Combining results of two GC separations partly achieves determination of all cis and trans 16:1, 18:1, 18:2 and 18:3 except CLA isomers of milk fat as demonstrated using ag-ion SPE fractionation. Lipids 43:259-273.

Labussière, J. 1988. Review of physiological and anatomical factors influencing the milking ability of ewes and the organization of milking. Livest. Prod. Sci. 18:253-274.

Lawlor, M., A. Louca, and A. Mavrogenis. 1974. The effect of three suckling regimes on the lactation performance of Cyprus fat-tailed, Chios and Awassi sheep and the growth rate of the lambs. Anim. Prod. 18:293-299.

Lock, A. L., C. Tyburczy, D. A. Dwyer, K. J. Harvatine, F. Destaillats, Z. Mouloungui, L. Candy, and D. E. Bauman. 2007. Trans-10 octadecenoic acid does not reduce milk fat synthesis in dairy cows. J. Nutr. 137:71-76.

Louca, A. 1972. The effect of suckling regime on growth rate and lactation performance of the Cyprus fat-tailed and Chios sheep. Anim. Prod. 15:53-59.
Lowry, O. H., N. J. Rosebrough, A. L. Faff, and R. J. Randall. 1951. Protein measurement with the folin phenol reagent. J. Biol. Chem. 193:265-275.

Marnet, P. G., and J. A. Negrão. 2000. The effect of a mixed-management system on the release of oxytocin, prolactin, and cortisol in ewes during suckling and machine milking. Reprod. Nutr. Dev. 40:271-281.

Marnet, P. G., and M. Komara. 2008. Management systems with extended milking intervals in ruminants: Regulation of production and quality of milk. J. Anim. Sci. 86:47-56.

McDonald, P. R. Edwards, J. Greenhalgh, and C. Morgan. 2002. Animal Nutrition. 6th ed. Prentice Hall, Harlow, UK.

McKusick, B. C., D. L. Thomas, and Y. M. Berger. 2001. Effect of weaning system on commercial milk production and lamb growth of East Friesian dairy sheep. J. Dairy Sci. 84:1660-1668.

McKusick, B. C., D. L. Thomas, J. E. Romero, and P. G. Marnet. 2002. Effect of weaning system on milk composition and distribution of milk fat within the udder of East Friesian dairy ewes. J. Dairy Sci. 85:2521-2528.

Mendoza, A., D. Cavestany, G. Roig, J. Ariztia, C. Pereira, A. La Manna, D. A. Contreras, and C. S. Galina. 2010. Effect of restricted suckling on milk yield, composition and flow, udder health, and postpartum anoestrus in grazing Holstein cows. Livest. Sci. 127:60-66.

NRC. 2007. Nutrient Requirements of Small Ruminants: Sheep, Goats, Cervids, and New World Camelids. Natl. Acad. Press, Washington, DC.

Papachristoforou, C. 1990. The effects of milking method and postmilking suckling on ewe milk production and lamb growth. Ann. Zootech. 39:1-8.

Park, Y., M. Juárez, M. Ramos, and G. Haenlein. 2007. Physico-chemical characteristics of goat and sheep milk. Small Rumin. Res. 68:88-113.

Pinheiro, J. C., and D. M. Bates. 2000. Mixed Effects Models in S and S-PLUS. Springer, New York, NY.

R Core Team. 2014 R: A Language and Environment for Statistical Computing. R Foundation for Statistical Computing, Vienna, Austria.

Rico, D. E., E. R. Marshall, J. Choi, K. E. Kaylegian, C. D. Dechow, and K. J. Harvatine. 2014. Within-milking variation in milk composition and fatty acid profile of Holstein dairy cows. J. Dairy Sci. 97:4259-4268.

Siri-Tarino, P. W., Q. Sun, F. B. Hu, and R. M. Krauss. 2010. Metaanalysis of prospective cohort studies evaluating the association of saturated fat with cardiovascular disease. Am. J. Clin. Nutr. 91:535-546.

Sterk, A., A. Van Vuuren, W. Hendriks, and J. Dijkstra. 2012. Effects of different fat sources, technological forms and characteristics of the basal diet on milk fatty acid profile in lactating dairy cows- $\mathrm{A}$ meta-analysis. J. Agric. Sci. 150:495-517.

Stoop, W. M., J. A. M. Van Arendonk, J. M. L. Heck, H. J. F. Van Valenberg, and H. Bovenhuis. 2008. Genetic parameters for major milk fatty acids and milk production traits of Dutch HolsteinFriesians. J. Dairy Sci. 91:385-394.

Tsiafoulis, C. G., T. Skarlas, O. Tzamaloukas, D. Miltiadou, and I. P. Gerothanassis. 2014. Direct nuclear magnetic resonance identification and quantification of geometric isomers of conjugated linoleic acid in milk lipid fraction without derivatization steps: Overcoming sensitivity and resolution barriers. Anal. Chim. Acta 821:62-71.

Walker, G. P., F. R. Dunshea, and P. T. Doyle. 2004. Effects of nutrition and management on the production and composition of milk fat and protein: A review. Aust. J. Agric. Res. 55:1009-1028.

WHO/FAO. 2002 Diet, nutrition and the prevention of chronic diseases: Report of a joint WHO/FAO expert consultation. Tech. Rep. Ser. 916. World Health Organization, Geneva, Switzerland. 